\title{
Direct inhibition by angiotensin II of insulin-dependent glucose transport activity in mammalian skeletal muscle involves a ROS- dependent mechanism
}

\author{
Maggie K. Diamond-Stanic and Erik J. Henriksen \\ Muscle Metabolism Laboratory, Department of Physiology and Arizona Diabetes Program, \\ University of Arizona College of Medicine, Tucson, AZ 85721-0093
}

\begin{abstract}
No previous study has investigated how the vaso-constrictive peptide Ang II impacts insulin action in isolated mammalian skeletal muscle. We investigated the molecular actions of Ang II on insulin signalling and glucose transport in skeletal muscle from lean Zucker rats. Soleus strips were incubated with insulin $(5 \mathrm{mU} / \mathrm{ml})$ and/or Ang II $(500 \mathrm{nM})$ for 2 hours. Ang II caused significant $(p<0.05)$ inhibition of insulin-stimulated glucose transport $(39 \%)$ and decreased phosphorylation of Akt $\operatorname{Ser}^{473}$ (37\%) and glycogen synthase kinase-3 $3 \operatorname{Ser}^{9}(42 \%)$ without affecting phosphorylation of IRS-1 Ser ${ }^{307}$ or p38 MAPK. We used the superoxide dismutase mimetic, tempol (1 mM), to determine if reactive oxygen species (ROS) contribute to Ang IImediated insulin resistance. Tempol partially reversed (42\%) Ang II-induced inhibition of insulinstimulated glucose transport. These results indicate that Ang II inhibits distal insulin signalling and insulin-stimulated glucose transport in isolated mammalian skeletal muscle, and that this effect is partially mediated by ROS.
\end{abstract}

\section{Keywords}

Soleus muscle; insulin resistance; insulin signalling; reactive oxygen species

\section{Introduction}

\begin{abstract}
Hypertension is a known risk factor for development of insulin resistance and type 2 diabetes. Individuals with hypertension have higher fasting glucose and insulin levels than non-hypertensive individuals (Gress et al., 2000) and patients with untreated hypertension are more likely to develop new-onset diabetes than non-hypertensive subjects (Gress et al., 2000). Elements of the renin-angiotensin system (RAS), specifically angiotensin II (Ang II), which is often elevated in hypertension, may induce insulin resistance. Treatment of hypertensive patients with angiotensin converting enzyme (ACE) inhibitors or an Ang II receptor antagonist has been found to improve fasting serum glucose concentrations (Gress et al., 2000; Bosch et al., 2006) and to decrease the incidence of new-onset diabetes (Hansson et al., 1999; Yusuf et al., 2000; Kjeldsen et al., 2002).
\end{abstract}

Administration of Ang II to non-hypertensive animals induces whole-body and skeletal muscle insulin resistance (Richey et al., 1999; Ogihara et al., 2002). The mRen2 transgenic 
rat, which carries the mouse Ren-2 renin gene leading to elevated activity of local RAS (Lee et al., 1996) and hypertension, are insulin-resistant (Blendea et al., 2005; Sloniger et al., 2005a; Sloniger et al., 2005b) secondary to defects in skeletal muscle insulin signalling and insulin-induced glucose transport activity (Sloniger et al., 2005a; Sloniger et al., 2005b). Treatment of mRen2 rats with angiotensin type 1 receptor (AT1R) blockers improves whole-body insulin sensitivity and insulin- stimulated skeletal muscle glucose transport activity, supporting a role of Ang II in the aetiology of insulin resistance (Blendea et al., 2005; Sloniger et al., 2005b). Similarly, treatment of obese Zucker rats, a monogenetic model of obesity-associated insulin resistance, with an ACE inhibitor or Ang II receptor antagonist improves glucose tolerance and insulin sensitivity (Henriksen et al., 1995; Henriksen et al., 2001).

The effects of Ang II on skeletal muscle insulin sensitivity may be mediated in part by alterations in blood flow (Jamerson et al., 1996; Richey et al., 1999). However, recent data suggest additional direct, non-haemodynamic effects of Ang II. For example, in smooth muscle cell cultures and in L6 myotubes, Ang II inhibited insulin signalling and diminished insulin-stimulated glucose transport (Folli et al., 1997; Wei et al., 2006; Wei et al., 2007). Several studies suggest that Ang II may stimulate increased production of reactive oxygen species (ROS), which in turn impairs insulin signalling (Blendea et al., 2005; Wei et al., 2006; Wei et al., 2007; Dokken et al., 2008).

Extrapolation of the results from studies utilizing muscle cells in culture can be confounded by potential alterations in the cells during the culture process. The direct effects of Ang II on skeletal muscle have not been well characterized in a model system that retains the function of intact skeletal muscle while eliminating haemodynamic and other secondary effects of Ang II. Therefore, in the present study we used isolated soleus muscle preparations to investigate the direct impact of Ang II on distal insulin signalling and insulin-stimulated glucose transport activity in mammalian skeletal muscle. We addressed the following hypotheses: (1) Ang II directly impairs insulin signalling and insulin-stimulated glucose transport in isolated, intact soleus muscle, and (2) the effect of Ang II on insulin signalling is at least partially mediated by ROS and can be rescued by treatment with tempol, a superoxide dismutase mimetic.

\section{Materials and methods}

\section{Animals}

All procedures were approved by the Institutional Animal Care and Use Committee at the University of Arizona. Female lean (Fa/?) Zucker rats (Harlan, Indianapolis, IN) were used at 9-10 weeks of age, when they had body weights of 150-170 g. Animals were housed in a temperature-controlled $\left(20-22^{\circ} \mathrm{C}\right)$ room with a 12:12-h light-dark cycle at the Central Animal Facility at the University of Arizona. The animals had free access to chow (Teklad 7001, Madison, WI) and water. At 5 pm the evening before each experiment, animals were restricted to $4 \mathrm{~g}$ of chow, which was consumed immediately. Experiments began between 8 and $10 \mathrm{am}$ the next morning.

\section{Muscle incubations and exposure to Ang II and tempol}

The animals were deeply anaesthetized with pentobarbital sodium (50 $\mathrm{mg} / \mathrm{kg}$ ip), and strips of soleus muscles $(\sim 25-35 \mathrm{mg})$ were prepared for in vitro incubation in the unmounted state. Muscles were initially incubated for $2-6 \mathrm{~h}$ at $37^{\circ} \mathrm{C}$ in oxygenated Krebs-Henseleit buffer (KHB) containing $8 \mathrm{mM}$ glucose, $32 \mathrm{mM}$ mannitol, and $0.1 \%$ bovine serum albumin (radioimmunoassay grade, Sigma Chemical), in the absence or presence of $5 \mathrm{mU} / \mathrm{ml}$ insulin (Humulin, Eli Lilly, Indianapolis, IN) without or with $500 \mathrm{nM}$ Ang II (Sigma Chemical, St. 
Louis. MO). For 4-h and 6-h incubations, muscles were transferred to fresh medium of identical composition every $2 \mathrm{~h}$. In a second set of experiments, muscle strips were incubated for $2 \mathrm{~h}$ in the presence of insulin without or with Ang II and/or tempol (1 mM; Sigma Chemical).

\section{Assessment of glucose transport activity}

Glucose transport activity in isolated soleus strips was assessed in vitro by determination of the intracellular accumulation of 2-deoxyglucose $(1 \mathrm{mM})$ in the absence or presence of a maximally effective concentration of insulin $(5 \mathrm{mU} / \mathrm{ml})$ as previously described (Henriksen et al., 1995). Briefly, after the initial incubation period, the muscles were rinsed for $10 \mathrm{~min}$ at $37^{\circ} \mathrm{C}$ in $3 \mathrm{ml}$ of oxygenated $\mathrm{KHB}$ containing $40 \mathrm{mM}$ mannitol, $0.1 \%$ BSA, and insulin, Ang II, and/or tempol, if present previously. Following the rinse period, the muscles were transferred to $2 \mathrm{ml}$ of $\mathrm{KHB}$ containing $1 \mathrm{mM}$ 2-deoxy-[1,2-3H]glucose (2-DG) $(0.3 \mathrm{mCi} /$ mmol; Sigma Chemical), $39 \mathrm{mM}\left[\mathrm{U}_{-}{ }^{14} \mathrm{C}\right] \mathrm{mannitol}(0.8 \mathrm{mCi} / \mathrm{mmol}$; ICN Radiochemicals, Irvine, CA), $0.1 \%$ BSA, and insulin, Ang II, and/or tempol, if previously present, and incubated for $20 \mathrm{~min}$ at $37^{\circ} \mathrm{C}$. At the end of this final incubation period, the muscles were removed, trimmed of excess fat and connective tissue, quickly frozen between aluminium blocks cooled with liquid nitrogen, weighed, and placed in $0.5 \mathrm{ml}$ of $0.5 \mathrm{mM} \mathrm{NaOH}$. After the muscles were completely solubilized, $5 \mathrm{ml}$ of scintillation cocktail was added, and the specific intracellular accumulation of 2-[3H]DG was determined as described previously (Henriksen et al., 1994; Henriksen et al., 1995).

\section{Determination of signalling protein expression and functionality}

In some experiments, muscles were frozen after the initial incubation period, weighed, and stored at $-80^{\circ} \mathrm{C}$ until analysis. These muscles were homogenized in $8 \mathrm{vol}$ of ice-cold lysis buffer (50 mM HEPES, $150 \mathrm{mM} \mathrm{NaCl}, 20 \mathrm{mM}$ Na pyrophosphate, $20 \mathrm{mM} \beta$ glycerophosphate, $10 \mathrm{mM} \mathrm{NaF}, 2 \mathrm{mM}$ Na3VO4, 2 mM EDTA, 1\% Triton X-100, 10\% glycerol, $1 \mathrm{mM} \mathrm{MgCl} 2,1 \mathrm{mM} \mathrm{CaCl} 2,10 \mu \mathrm{g} / \mathrm{ml}$ aprotinin, $10 \mu \mathrm{g} / \mathrm{ml}$ leupeptin, $0.5 \mu \mathrm{g} / \mathrm{ml}$ pepstatin, and $2 \mathrm{mM}$ PMSF). Homogenates were incubated on ice for $20 \mathrm{~min}$ and then centrifuged at $13,000 \times \mathrm{g}$ for $20 \mathrm{~min}$ at $4^{\circ} \mathrm{C}$. Total protein concentration was determined using the BCA method (Sigma Chemical). Samples containing equal amounts of total protein were separated by SDS-PAGE on $7.5 \%$ or $10 \%$ polyacrylamide gels and transferred to nitrocellulose. Membranes were incubated overnight with antibodies against phosphorylated Akt Ser ${ }^{473}$ (Cell Signaling Technology, Danvers, MA), phosphorylated glycogen synthase kinase-3 $\beta$ (GSK-3 $\beta$ ) Ser ${ }^{21 / 9}$ (Millipore, Billerica, MA), phosphorylated p38 MAPK Thr ${ }^{180} /$ Tyr $^{182}$ (Cell Signaling)), phosphorylated IRS-1 Ser ${ }^{307}$ (Millipore), or antibodies against total Akt (Cell Signaling), GSK-3 $\beta$ (Millipore), p38 MAPK (Cell Signaling), or IRS-1 (Millipore). In our hands, $\mathrm{Ser}^{21}$ phosphorylation of GSK-3 $\alpha$ in muscle from lean Zucker rats is very low (unpublished data), and all GSK-3 data in this study are therefore restricted to $\operatorname{Ser}^{9}$ phosphorylation of GSK-3 $\beta$. The membranes were incubated with secondary goat anti-rabbit antibody conjugated with horse radish peroxidase (HRP) (Chemicon, Temecula, CA) or anti-mouse antibody conjugated with HRP (Santa Cruz Biotechnology, Santa Cruz, CA) following the incubation with the primary antibody. The proteins were visualized using a Bio-Rad Chemidoc XRS instrument (Bio-Rad Laboratories, Hercules, CA) using the SuperSignal West Femto Maximum Sensitivity Western blot detection substrate (Pierce, Rockford, IL). Band density was quantified using the Bio-Rad Quantity One software.

\section{Statistical analysis}

Values are presented as mean \pm SEM. Paired Student's $t$-tests were employed to determine statistically significant differences in group means when soleus splits derived from the same 
muscle were used to assess the specific effects of Ang II or the superoxide dismutase mimetic tempol. A $p$-value less than 0.05 was considered statistically significant.

\section{Results}

\section{Effects of Ang II on glucose transport activity}

To determine the impact of Ang II on glucose transport activity, isolated soleus muscle strips were incubated for $2 \mathrm{~h}$ with Ang II $(500 \mathrm{nM})$ in the absence or presence of a maximally-effective concentration of insulin (Figure 1). This dose of Ang II was the lowest maximally-effective concentration found to induce insulin resistance, derived from experiments using incubations up to $6 \mathrm{~h}$ in duration (data not shown). This dose of Ang II is similar to that used by others in previous experiments in cell culture (Folli et al., 1997; Wei et al., 2006; Wei et al., 2007), and suggests that the effect of Ang II is mediated by the angiotensin type 1 receptor. Ang II alone had no effect on glucose transport activity, whereas insulin alone caused a nearly three-fold increase in this parameter. However, Ang II inhibited the insulin-induced increase in glucose transport by 39\% $(p<0.05)$. This Ang IIinduced insulin resistance was not complete, as the rate of glucose transport activity in the presence of Ang II and insulin remained significantly above $(176 \%, p<0.05)$ the basal rate $(p<0.05)$. The Ang II-associated reduction in insulin-stimulated glucose transport activity was also seen after 4-h and 6-h exposures (Figure 1).

\section{Effects of Ang II on signalling element protein expression and functionality}

To determine if the Ang II-induced insulin resistance of glucose transport activity (Figure 1) was associated with defects in insulin signalling, select signalling factors involved in the regulation of the glucose transport system in skeletal muscle were evaluated (Figure 2). Ang II exposure for $2 \mathrm{~h}$ had no effect on the phosphorylation of either Akt Ser ${ }^{473}$ (Figure 2, top left panel) or GSK-3 $\beta \operatorname{Ser}^{9}$ (Figure 2, bottom left panel). Insulin increased phosphorylation of Akt Ser ${ }^{473}$ by $271 \%$ (Figure 2) and GSK-3 $\beta$ Ser ${ }^{9}$ by $314 \%$ (Figure 2). Importantly, Ang II significantly suppressed insulin-stimulated Akt phosphorylation by $37 \%$ and GSK-3 $\beta$ phosphorylation by $58 \%$ (both $p<0.05$ ). Interestingly, while the decrease in insulinmediated Akt Ser ${ }^{473}$ phosphorylation was still evident after longer-term exposures to Ang II, the Ang II-mediated decrease in GSK-3 $\beta$ Ser ${ }^{9}$ phosphorylation had returned to control levels at the $4 \mathrm{hr}$ and $6 \mathrm{hr}$ time points (Figure 2, middle and right panels). Akt and GSK-3 $\beta$ protein expression was not affected by Ang II or insulin at any of the time points (data not shown).

GSK-3 $\beta$ is a serine kinase capable of inhibitory serine phosphorylation of IRS-1 (Liberman et al., 2005; Henriksen et al., 2007). Therefore, IRS-1 Ser ${ }^{307}$ phosphorylation was evaluated in skeletal muscle exposed to Ang II for $2 \mathrm{~h}$. Neither Ang II nor insulin, alone or in combination, significantly affected this variable (Basal: $100 \pm 10 \%$, Ang II: $114 \pm 16 \%$, Insulin: $112 \pm 19 \%$, Insulin + Ang II: $96 \pm 15 \%$ ). In addition, phosphorylation on $\mathrm{Thr}^{180}$ / $\mathrm{Tyr}^{182}$ of $\mathrm{p} 38 \mathrm{MAPK}$, a serine kinase engaged by oxidative stress in skeletal muscle (Kim et al., 2006; Dokken et al., 2008; Archuleta et al., 2009), was likewise not altered by treatment with Ang II and/or insulin (Basal: $100 \pm 25$; Ang II: $142 \pm 41$; Insulin: $124 \pm 33$; Insulin + Ang II: $107 \pm 26 \%$ ).

\section{Effect of tempol on Ang II-induced inhibition of insulin action}

Previous studies have demonstrated that Ang II activates NADPH oxidase, resulting in increased ROS production in skeletal muscle cells (Griendling et al., 2000; Wei et al., 2006). ROS, in turn, can impair insulin signalling and insulin-stimulated glucose transport (Kim et al., 2006; Dokken et al., 2008; Archuleta et al., 2009; Vichaiwong et al., 2009). To determine if ROS plays a role in the Ang II-induced insulin resistance in skeletal muscle (Figure 1), we employed the superoxide dismutase mimetic, tempol. As shown in Figure 3, 
tempol had no significant effect on insulin-stimulated glucose transport in the absence of Ang II. The insulin-stimulated glucose transport activity in the presence of Ang II was 72\% of the value in the presence of insulin alone. However, when tempol was present with insulin and Ang II, the rate of glucose transport was increased significantly $(p<0.05)$ to $87 \%$ of the insulin-stimulated value in the absence of Ang II, although this value remained significantly less than this control activity.

The effects of tempol on the ANG II-induced defects in insulin-stimulation of Akt Ser ${ }^{473}$ and GSK-3 $\beta \operatorname{Ser}^{9}$ phosphorylation were also evaluated (Figure 4). Tempol alone did not significantly alter insulin stimulation of GSK-3 $\beta$ (Figure 4, right panel). However, the tempol treatment did significantly reduce insulin-stimulated Akt phosphorylation (Figure 4, left panel). Tempol did not significantly affect the Ang II-induced inhibition of insulinstimulated Akt or GSK-3 $\beta$ phosphorylation. Tempol had no effect on total Akt or total GSK- $3 \beta$ protein levels (data not shown).

\section{Discussion}

In the present study, we have demonstrated for the first time that the vaso-constrictive peptide Ang II directly impairs insulin-stimulated glucose transport activity in isolated mammalian skeletal muscle (Figure 1), in which haemodynamic influences cannot modulate glucose disposal. This inhibitory effect of a 2 -h exposure to Ang II occurred coincidentally with impairment of insulin-stimulated phosphorylation of Akt Ser ${ }^{473}$ and GSK-3 $\beta$ Ser $^{9}$ (Figure 2). Furthermore, we have shown in this investigation that treatment of isolated skeletal muscle with tempol, a superoxide dismutase mimetic, partially (42\%) rescues the Ang II-induced inhibition of insulin-stimulated glucose transport activity (Figure 3), suggesting that ROS may mediate part of the effect of Ang II on this process. Our data support the hypothesis that Ang II can directly induce insulin resistance in mammalian skeletal muscle by a ROS-dependent mechanism.

Previous studies have suggested that Ang II induces skeletal muscle insulin resistance. Chronic infusion of normal rats with Ang II resulted in a 63\% decrease in insulin action on in vitro muscle glucose transport activity (Ogihara et al., 2002). Interestingly, this Ang IIinduced decrease in insulin-stimulated glucose transport activity was accompanied by increases in the activities of elements of the proximal and distal insulin signalling pathway. For example, chronic in vivo infusion of Ang II resulted in 2.3-fold increase in insulinstimulated Akt phosphorylation (Ogihara et al., 2002). These data are in direct contrast to the findings of the present investigation, in which we observed a 39\% reduction in insulinstimulated glucose transport activity and comparable decreases in insulin-stimulated serine phosphorylation of Akt and GSK-3 $\beta$ in the presence of Ang II. These contradictory results may be due to differences in the route of administration and duration of exposure to Ang II. In the present study, we used an acute 2-h exposure of isolated skeletal muscle to Ang II, while Ogihara and colleagues (Ogihara et al., 2002) used a chronic (2-week) exposure of Ang II administered systemically by osmotic mini-pump to the animals.

Other studies have reported that the mRen2 rat, a model of chronic RAS overactivity, displays decreased insulin-stimulated glucose transport activity in skeletal muscle associated with decreased insulin-stimulated serine phosphorylation of Akt and GSK-3 $\beta$ (Sloniger $e t$ al., 2005a). Interestingly, while treatment with an Ang II type 1A receptor blocker improved insulin-stimulated glucose transport activity in these rats, it had no affect on the phosphorylation state of elements of the insulin signalling cascade (Sloniger et al., 2005b). Finally, in cultured L6 myotubes, Ang II inhibited insulin-stimulated Akt phosphorylation and decreased plasma membrane GLUT4 protein following insulin stimulation (Wei et al., 
2006), further supporting the hypothesis that Ang II impairs insulin signalling in skeletal muscle.

Ang II stimulates increased production of superoxide radical via activation of NADPH oxidase, with the superoxide being rapidly converted to the oxidant $\mathrm{H}_{2} \mathrm{O}_{2}$ (Griendling et al., 2000). We have previously shown that acute, low-level $\mathrm{H}_{2} \mathrm{O}_{2}$ exposure in vitro impairs insulin-stimulated glucose transport activity and phosphorylation of Akt and GSK-3 $\beta$ in intact soleus muscle strips (Kim et al., 2006; Dokken et al., 2008; Archuleta et al., 2009; Vichaiwong et al., 2009). Similarly, in L6 myotubes, ROS mediates the negative effects of Ang II on insulin signalling (Wei et al., 2006). Moreover, chronic treatment of mRen2 rats with tempol partially normalizes insulin-stimulated glucose transport activity in skeletal muscle (Blendea et al., 2005). To test whether ROS plays a role in the deleterious effect of Ang II on insulin action in isolated mammalian skeletal muscle, we also employed this superoxide radical scavenger. Tempol treatment partially ameliorated (42\% recovery) the Ang II-induced decrease in insulin-stimulated glucose transport activity (Figure 3). Similar results have been obtained in rats chronically infused with Ang II and tempol, in which tempol rescued the Ang II-induced decrease in whole-body glucose disposal and insulinstimulated glucose transport activity in isolated skeletal muscle (Ogihara et al., 2002). These data suggest that that effect of Ang II on insulin-stimulated glucose transport activity in muscle is at least partially mediated by the Ang II-induced increase in ROS.

While we did not measure NADPH oxidase in the present study, there are data in the literature supporting the possibility the Ang II elevates NADPH oxidase activity in muscle. NADPH oxidase activity is elevated in aortas of mRen2 rats compared with SpragueDawley rats, and this activity is AT1R-dependent, as treatment of mRen2 rats with valsartan normalized aortic NADPH oxidase activity (Wei, 2007). Furthermore, in cultured L6 myotubes, Ang II increased NADPH oxidase consumption via a receptor-dependent mechanism (Wei, 2006), and Ang II has been shown to increase protein expression of the NADPH oxidase subunit gp91 ${ }^{\text {phox }}$ coincident with an increase in ROS (Zhao, 2006). Finally, in rats made diabetic with streptozotocin treatment, the hyperglycaemic state is associated with increased NADPH oxidase activity and $\mathrm{p} 22^{\text {phox }}$ subunit protein expression in quadriceps muscle, and treatment of these diabetic rats with candesartan significantly decreased these parameters (Dorenkamp, 2005).

Interestingly, we have shown previously that $\mathrm{H}_{2} \mathrm{O}_{2}(60-90 \mu \mathrm{M})$ in vitro stimulates glucose transport activity in isolated skeletal muscle (Kim et al., 2006; Dokken et al., 2008; Archuleta et al., 2009; Vichaiwong et al., 2009). In the present study, Ang II at $500 \mathrm{nM}$ had no effect on this parameter (Figure 1). Furthermore, we have reported previously that $\mathrm{H}_{2} \mathrm{O}_{2}$ increases IRS-1 Ser ${ }^{307}$ phosphorylation, an effect associated with diminished IRS-1 tyrosine phosphorylation and insulin resistance of muscle glucose transport activity (Archuleta et al., 2009). However, in the present investigation, we did not observe any effect of Ang II on basal or insulin-stimulated IRS-1 Ser ${ }^{307}$ phosphorylation. $\mathrm{H}_{2} \mathrm{O}_{2}$ alone and in the presence of insulin increases phosphorylation of p38 MAPK (Dokken et al., 2008; Archuleta et al., 2009; Vichaiwong et al., 2009), an effect that was not mimicked in the present study by treatment with Ang II. These differences between our previous studies using $\mathrm{H}_{2} \mathrm{O}_{2}$ produced in vitro by glucose oxidase provision and the present investigation using Ang II are likely due to a lower level of oxidant stress induced by Ang II. Our data suggest that Ang II impairs insulin signalling and insulin-stimulated glucose transport activity via both ROSdependent and ROS-independent mechanisms.

While several previous investigations have suggested that Ang II induces insulin resistance in skeletal muscle, interpretation of these studies regarding potential direct effects of Ang II on the skeletal muscle glucose transport has been difficult. Ang II is a potent 
vasoconstrictor, and its haemodynamic actions in vivo may alter glucose and/or insulin delivery to skeletal muscle tissue. Indeed, whole animal studies have attempted to isolate the direct effects of Ang II on insulin signalling from haemodynamic effects, with conflicting results (Jamerson et al., 1996; Richey et al., 1999). In addition, while previous investigations have utilized cultured muscle cells to determine the direct actions of Ang II on insulin signalling and glucose transport (Folli et al., 1997; Wei et al., 2006), extrapolation of results from cell culture experiments is complicated by potential changes in cells during culture. Therefore, the results of the present investigation, obtained using isolated skeletal muscle preparations from normal rats, demonstrate unequivocally for the first time that Ang II can directly inhibit insulin action on distal insulin signalling and glucose transport activity, independent of any haemodynamic effects and in actual mammalian skeletal muscle tissue.

\section{Conclusions}

Hypertension and insulin resistance are both components of the metabolic syndrome, and hypertension is an independent risk factor for the development of insulin resistance. Ang II, which is frequently elevated in hypertension, may be a link between hypertension and insulin resistance. Treatment of hypertensive patients with ACE inhibitors or the Ang II receptor antagonists improves fasting serum glucose concentrations (Gress et al., 2000; Bosch et al., 2006) and decreases the incidence of new-onset diabetes (Hansson et al., 1999; Yusuf et al., 2000; Kjeldsen et al., 2002). Collectively, the results of the present study provide direct evidence that Ang II can induce skeletal muscle insulin resistance via increased oxidative stress, and thus support a role for Ang II as a common link in the aetiology of hypertension and insulin resistance.

\section{Abbreviations}

2-DG

Ang II

ACE

AT1R

GSK-3

KHB

IRS-1

p38 MAPK

ROS

RAS

\section{2-deoxyglucose}

angiotensin II

angiotensin converting enzyme

angiotensin II sub-type 1 receptor

glycogen synthase kinase-3

Krebs-Henseleit buffer

insulin receptor substrate-1

p38 mitogen-activated protein kinase

reactive oxygen species

renin-angiotensin system

\section{Acknowledgments}

The study was supported by grants DK063967 and T32 HL07249 from the National Institutes of Health.

\section{References}

Archuleta TL, Lemieux AM, Saengsirisuwan V, Teachey MK, Lindborg KA, Kim JS, Henriksen EJ. Oxidant stress- induced loss of IRS-1 and IRS-2 proteins in rat skeletal muscle: role of p38 MAPK. Free Radic Biol Med. 2009; 47:1486-1493. [PubMed: 19703555] 
Blendea MC, Jacobs D, Stump CS, McFarlane SI, Ogrin C, Bahtyiar G, Stas S, Kumar P, Sha Q, Ferrario CM, et al. Abrogation of oxidative stress improves insulin sensitivity in the Ren-2 rat model of tissue angiotensin II overexpression. Am J Physiol Endocrinol Metab. 2005; 288:E353E359. [PubMed: 15494608]

Bosch J, Yusuf S, Gerstein HC, Pogue J, Sheridan P, Dagenais G, Diaz R, Avezum A, Lanas F, Probstfield J, et al. Effect of ramipril on the incidence of diabetes. N Engl J Med. 2006; 355:15511562. [PubMed: 16980380]

Dokken BB, Saengsirisuwan V, Kim JS, Teachey MK, Henriksen EJ. Oxidative stress-induced insulin resistance in rat skeletal muscle: role of glycogen synthase kinase-3. Am J Physiol Endocrinol Metab. 2008; 294:E615-E621. [PubMed: 18089761]

Dorenkamp M, Riad A, Stiehl S, Spillmann F, Westermann D, Du J, Pauschinger M, Noutsias M, Adams V, Schultheiss H-P, et al. Protection against oxidative stress in diabetic rats: role of angiotensin AT1 receptor and beta 1-adrenoreceptor antagonism. Eur J Pharmacol. 2005; 520:179_ 187. [PubMed: 16139267]

Folli F, Kahn CR, Hansen H, Bouchie JL, Feener EP. Angiotensin II inhibits insulin signalling in aortic smooth muscle cells at multiple levels. A potential role for serine phosphorylation in insulin/ angiotensin II crosstalk. J Clin Invest. 1997; 100:2158-2169. [PubMed: 9410892]

Gress TW, Nieto FJ, Shahar E, Wofford MR, Brancati FL. Hypertension and antihypertensive therapy as risk factors for type 2 diabetes mellitus. Atherosclerosis risk in communities study. N Engl J Med. 2000; 342:905-912. [PubMed: 10738048]

Griendling KK, Ushio-Fukai M. Reactive oxygen species as mediators of angiotensin II signalling. Regul Pept. 2000; 91:21-27. [PubMed: 10967199]

Hansson L, Lindholm LH, Niskanen L, Lanke J, Hedner T, Niklason A, Luomanmaki K, Dahlof B, de Faire U, Morlin C, et al. Effect of angiotensin-converting-enzyme inhibition compared with conventional therapy on cardiovascular morbidity and mortality in hypertension: the Captopril Prevention Project (CAPPP) randomised trial. Lancet. 1999; 353:611-616. [PubMed: 10030325]

Henriksen EJ, Halseth AE. Early alterations in soleus GLUT-4, glucose transport, and glycogen in voluntary running rats. J Appl Physiol. 1994; 76:1862-1867. [PubMed: 8063642]

Henriksen EJ, Jacob S. Effects of captopril on glucose transport activity in skeletal muscle of obese Zucker rats. Metabolism. 1995; 44:267-272. [PubMed: 7869926]

Henriksen EJ, Jacob S, Kinnick TR, Teachey MK, Krekler M. Selective angiotensin II receptor receptor antagonism reduces insulin resistance in obese Zucker rats. Hypertension. 2001; 38:884890. [PubMed: 11641303]

Henriksen EJ, Teachey MK. Short-term in vitro inhibition of glycogen synthase kinase 3 potentiates insulin signalling in type I skeletal muscle of Zucker Diabetic Fatty rats. Metabolism. 2007; 56:931-938. [PubMed: 17570255]

Jamerson KA, Nesbitt SD, Amerena JV, Grant E, Julius S. Angiotensin mediates forearm glucose uptake by hemodynamic rather than direct effects. Hypertension. 1996; 27:854-858. [PubMed: 8613260]

Kim JS, Saengsirisuwan V, Sloniger JA, Teachey MK, Henriksen EJ. Oxidant stress and skeletal muscle glucose transport: roles of insulin signalling and p38 MAPK. Free Radic Biol Med. 2006; 41:818-824. [PubMed: 16895802]

Kjeldsen SE, Dahlof B, Devereux RB, Julius S, Aurup P, Edelman J, Beevers G, de Faire U, Fyhrquist $\mathrm{F}$, Ibsen $\mathrm{H}$, et al. Effects of losartan on cardiovascular morbidity and mortality in patients with isolated systolic hypertension and left ventricular hypertrophy: a Losartan Intervention for Endpoint Reduction (LIFE) substudy. JAMA. 2002; 288:1491-1498. [PubMed: 12243636]

Lee MA, Bohm M, Paul M, Bader M, Ganten U, Ganten D. Physiological characterization of the hypertensive transgenic rat TGRmREN2)27. Am J Physiol Endocrinol Metab. 1996; 270:E919E929.

Liberman Z, Eldar-Finkelman H. Serine 332 phosphorylation of insulin receptor substrate-1 by glycogen synthase kinase-3 attenuates insulin signalling. J Biol Chem. 2005; 280:4422-4428. [PubMed: 15574412] 
Ogihara T, Asano T, Ando K, Chiba Y, Sakoda H, Anai M, Shojima N, Ono H, Onishi Y, Fujishiro M, et al. Angiotensin II-induced insulin resistance is associated with enhanced insulin signalling. Hypertension. 2002; 40:872-879. [PubMed: 12468572]

Richey JM, Ader M, Moore D, Bergman RN. Angiotensin II induces insulin resistance independent of changes in interstitial insulin. Am J Physiol Endocrinol Metab. 1999; 277:E920-E926.

Sloniger JA, Saengsirisuwan V, Diehl CJ, Dokken BB, Lailerd N, Lemieux AM, Kim JS, Henriksen EJ. Defective insulin signalling in skeletal muscle of the hypertensive TG(mREN2)27 rat. Am J Physiol Endocrinol Metab. 2005a; 288:E1074-E1081. [PubMed: 15657091]

Sloniger JA, Saengsirisuwan V, Diehl CJ, Kim JS, Henriksen EJ. Selective angiotensin II receptor antagonism enhances whole-body insulin sensitivity and muscle glucose transport in hypertensive TG(mREN2)27 rats. Metabolism. 2005b; 54:1659-1668. [PubMed: 16311101]

Vichaiwong K, Henriksen EJ, Toskulkao C, Prasannarong M, Bupha-Intr T, Saengsirisuwan V. Attenuation of oxidant-induced muscle insulin resistance and p38 MAPK by exercise training. Free Radic Biol Med. 2009; 47:593-599. [PubMed: 19500665]

Wei Y, Sowers JR, Nistala R, Gong H, Uptergrove GM, Clark SE, Morris EM, Szary N, Manrique C, Stump CS. Angiotensin II-induced NADPH oxidase activation impairs insulin signalling in skeletal muscle cells. J Biol Chem. 2006; 281:35137-35146. [PubMed: 16982630]

Wei Y, Whaley-Connell AT, Chen K, Habibi J, Uptergrove GM, Clark SE, Stump CS, Ferrario CM, Sowers JR. NADPH oxidase contributes to vascular inflammation, insulin resistance, and remodeling in the transgenic (mRen2) rat. Hypertension. 2007; 50:384-391. [PubMed: 17533199]

Yusuf S, Sleight P, Pogue J, Bosch J, Davies R, Dagenais G. Effects of an angiotensin-convertingenzyme inhibitor, ramipril, on cardiovascular events in high-risk patients. The Heart Outcomes Prevention Evaluation Study Investigators. N Engl J Med. 2000; 342:145-153. [PubMed: 10639539] 


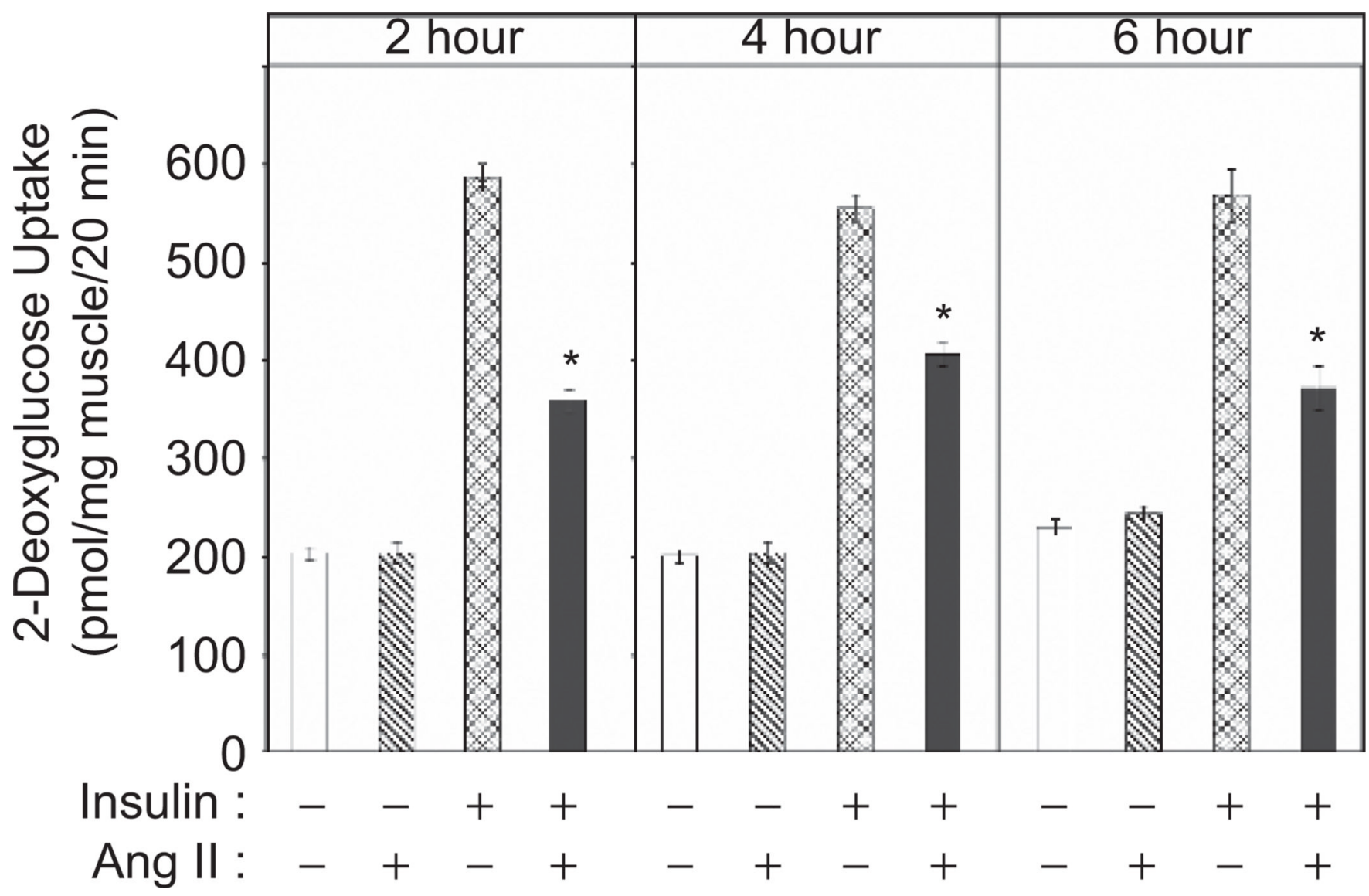

Figure 1.

Effect of 2-, 4-, or 6-hour exposure to Ang II on insulin-stimulated glucose transport activity in skeletal muscle of lean Zucker rats. Values are mean \pm SEM for 4 muscles per group. ${ }^{*} p$ $<0.05$ vs. paired muscle in the presence of insulin without Ang II. 


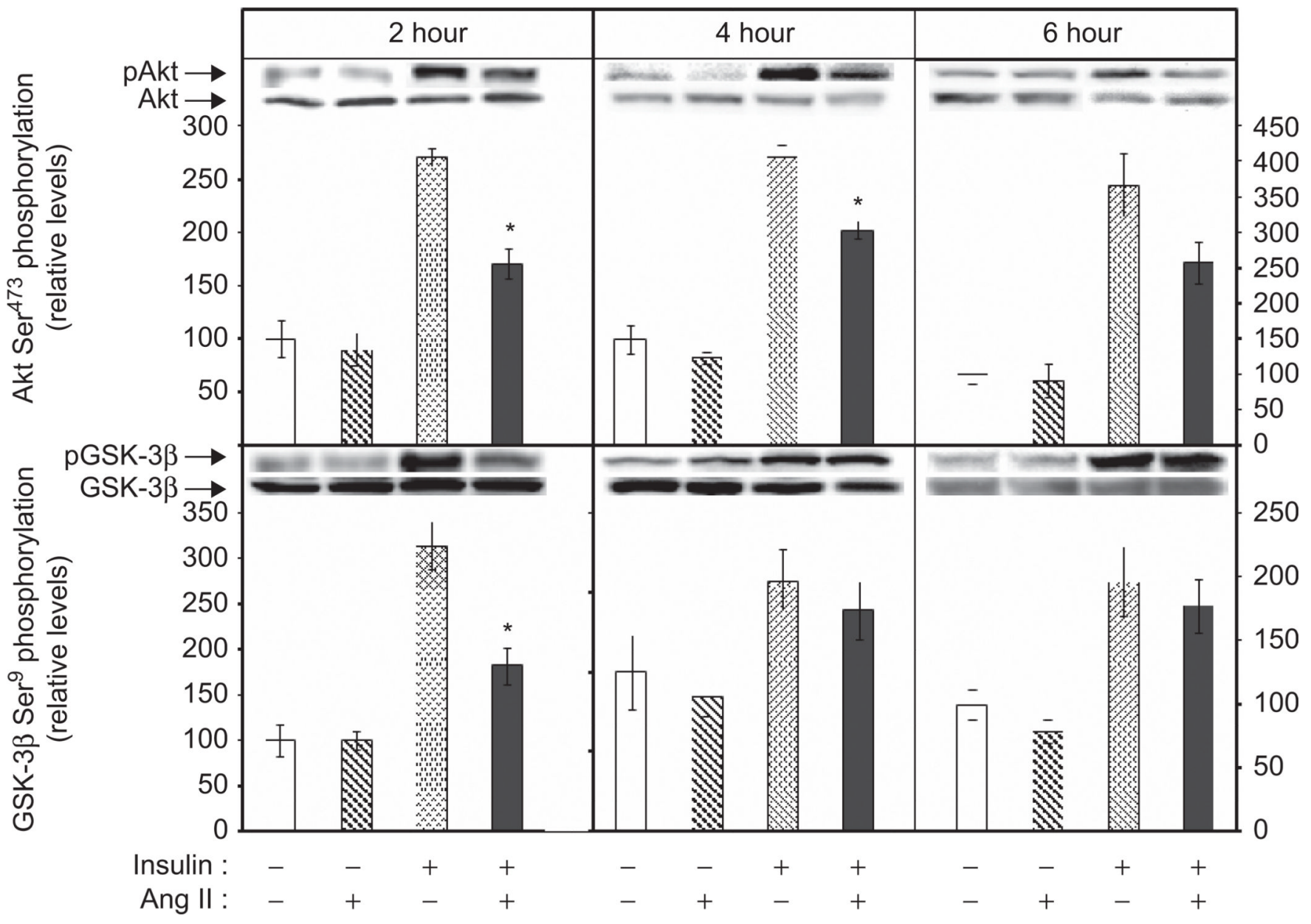

Figure 2.

Effects of 2-, 4-, or 6-hour exposure to Ang II on basal and insulin-stimulated phosphorylation of Akt Ser ${ }^{473}$ and GSK-3 $\beta$ Ser $^{9}$ in skeletal muscle of lean Zucker rats. Values are mean \pm SEM for $3-8$ muscles per group. ${ }^{*} p<0.05$ vs. paired muscle in the presence of insulin without Ang II. 


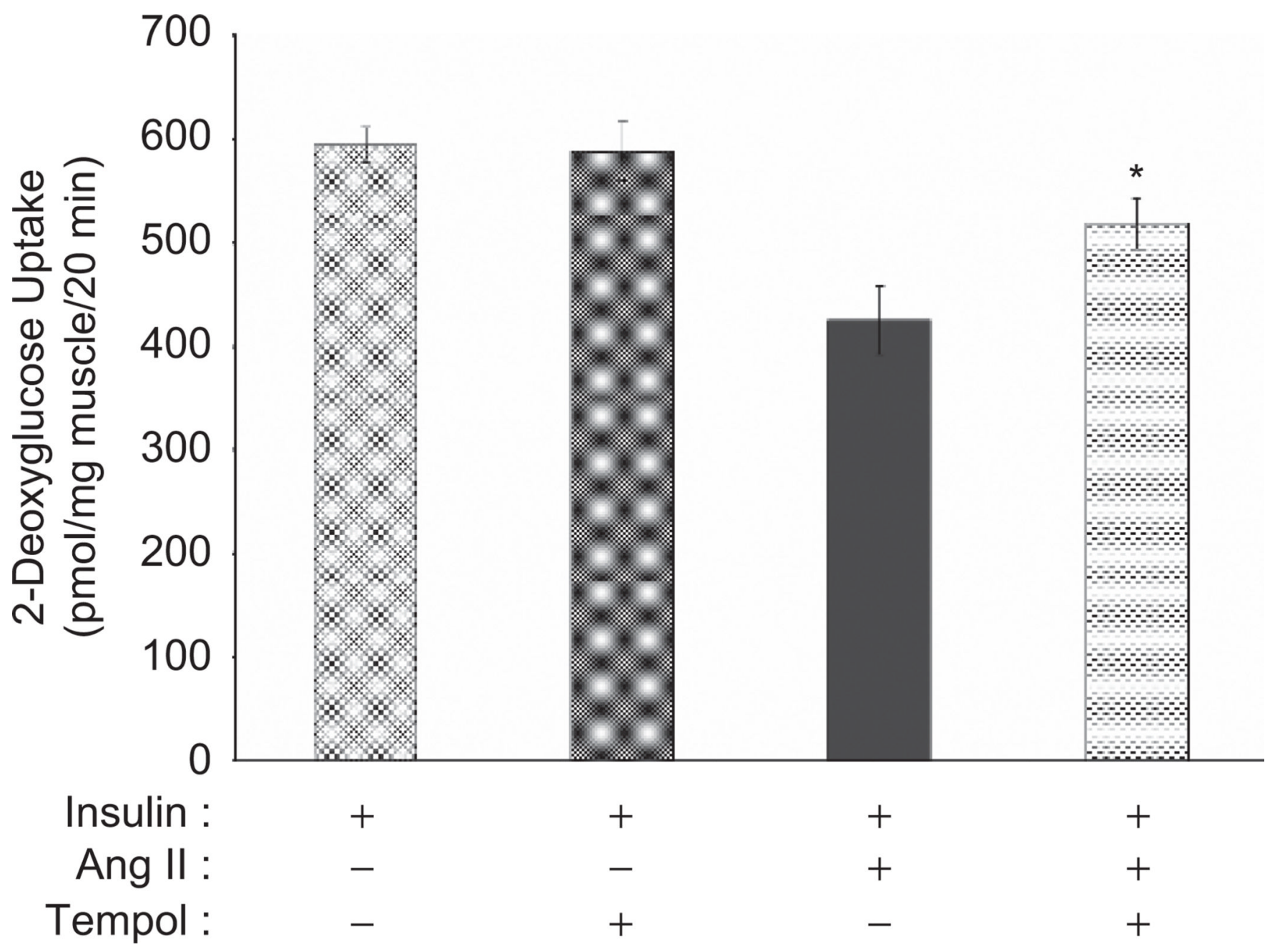

Figure 3.

Effect of tempol on Ang II-induced inhibition of insulin-stimulated glucose transport activity in skeletal muscle of lean Zucker rats. Values are mean \pm SEM for 4 muscles per group. ${ }^{*} p<0.05$ vs. paired muscle in the presence of insulin and Ang II without tempol. 


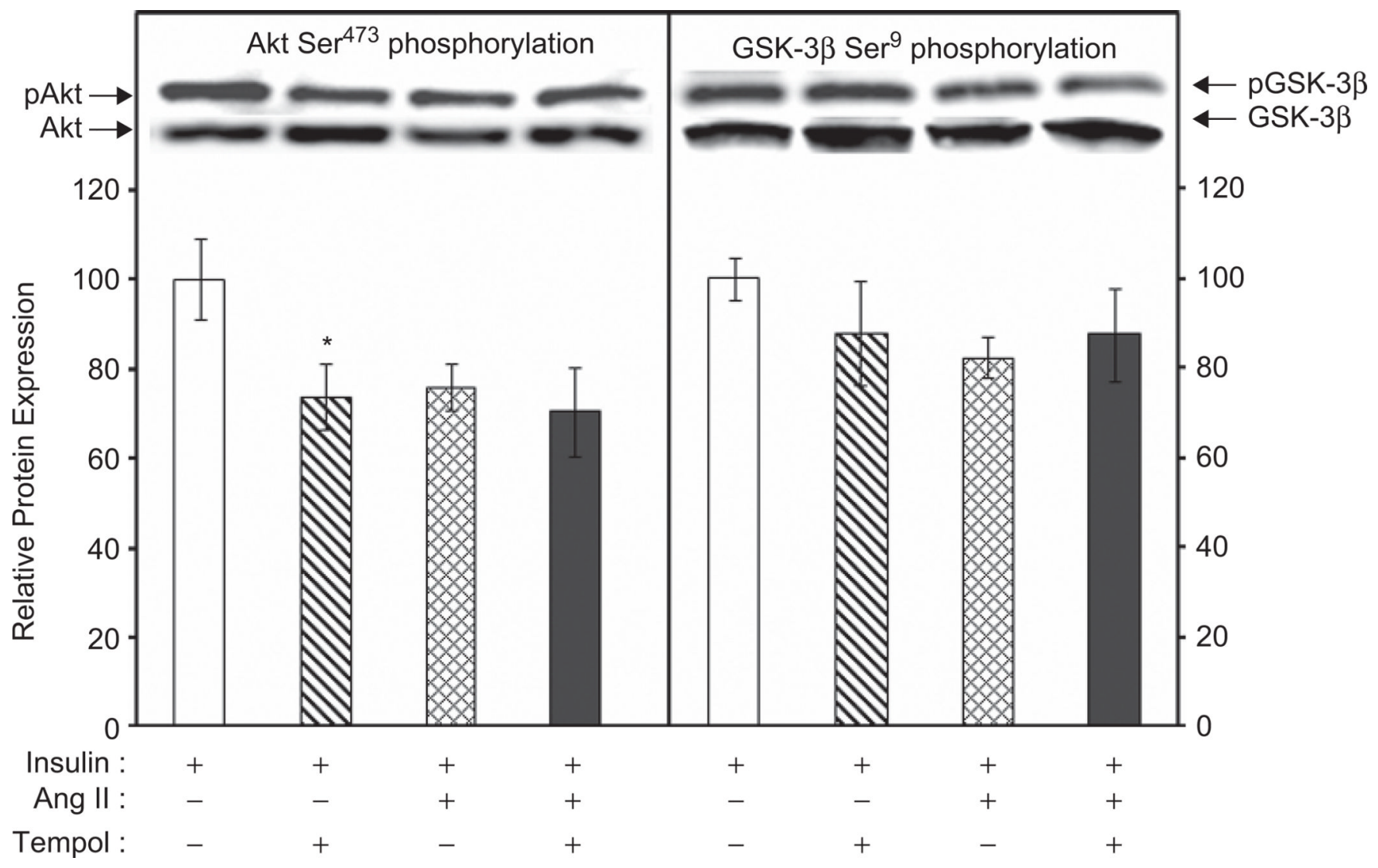

Figure 4.

Effect of tempol on Ang II inhibition of insulin-stimulated phosphorylation of Akt Ser ${ }^{473}$ and GSK-3 $\beta$ Ser $^{9}$ in skeletal muscle of lean Zucker rats. Values are mean \pm SEM for 6-7 muscles per group. 